\title{
Possible Health Benefits of Polyphenols in Neurological Disorders Associated with COVID-19
}

\author{
Johnson Olaleye Oladele ${ }^{1}$, Oluwaseun Titilope Oladele ${ }^{2}$, Oyedotun Moses Oyeleke ${ }^{1}$ \\ ${ }^{1}$ Kings University, Department of Chemical Sciences, Biochemistry Unit, Ode-Omu, Osun State, Nigeria \\ ${ }^{2}$ Osun State University, Department of Biochemistry, Phytomedicine and Molecular Toxicology Research Laboratories, \\ Osogbo, Nigeria
}

SUMMARY

Novel Coronavirus disease 2019 (COVID-19) represents an emergent global health burden that has challenged the health systems worldwide. Since its sudden upsurge in 2019, many COVID-19 patients have exhibited neurological symptoms and complications. Till now, there is no known effective established drug against the highly contagious COVID-19 infection despite the frightening associated mortality rate. This article aims to present the mechanism of action of coronavirus-2 (SARS-CoV-2), the clinical neurological manifestations displayed by COVID-19 patients, and present polyphenols with neuroprotective ability that can offer beneficial effects against COVID-19-mediated neuropathology. Reports from COVID-19 clinical studies, case reports, and other related literature were evaluated for this review. Neurological complications of COVID-19 include anosmia, acute cerebrovascular disease, acute disseminated post-infectious encephalomyelitis, encephalitis, etc. Also, SARS-CoV-2 could be a neurotropic virus due to its isolation from cerebrospinal fluid. Multiple neurological damages displayed by COVID-19 patients might be due to hyperinflammation associated with SARS-CoV-2 infections. Resveratrol, kolaviron, quercetin and apigenin are polyphenols with proven anti-inflammatory and therapeutic properties that can extenuate the adverse effects of COVID-19. These polyphenols have been documented to suppress c-Jun N- terminal kinase (JNK), phosphoinositide-3-kinase (PI3-K), extracellularsignal-regulated kinase (ERK), nuclear factor kappa-light-chain-enhancer of activated B-cells (NF-kB) and mitogen-activated protein kinase (MAPK) pathways which are essential in the pathogenesis of COVID-19. They also showed significant inhibitory activities against SARS-CoV-2 proteins. Taken together, these polyphenols may offer neuroprotective benefits against COVID-19 mediated neuropathology via modulation of the pathogenic pathways.

Key words: neuropathology, polyphenols, COVID-19, SARS-CoV-2, kolaviron; apigenin, quercetin

Corresponding author:

Johnson O. Oladele

e-mail: oladelejohn2007@gmail.com, jo.oladele@kingsuniversity.edu.ng 


\section{INTRODUCTION}

COVID-19 novel coronavirus pneumonia is ranked amidst the nine deadliest global pandemics that ever occurred in the world. It was first recorded in 2019 at Wuhan, a Chinese city, and since its first outbreak, the pandemic has dispersed wide to every region of the globe having critical negative impact on many countries of both developed and developing nations. This severe acute respiratory disease is highly contagious and transmissible via a pathogenic virus called SARS-CoV-2 to humans and animals. Reports by the world health organization (WHO) team on COVID-19 pandemic as of 25 November 2020 showed that COVID-19 has really inflicted great havoc on human health and constitutes a major danger to global public health. It was reported that over 57.8 million cases of SARS-CoV-2 infections have been recorded with over 1.3 million deaths globally $(1,2)$. In Nigeria, the most populous country in Africa, over 66,000 cases had been confirmed and more than 1,160 mortalities recorded $(1,2)$.

COVID-19 has an average incubation period of 3 days (3). The most prevalent medical manifestations of COVID-19 (such as cough, fever, shortness of breath, fatigue, and other complications) are nearly the same to those of other viral pneumonias; multiple organ failures and death were documented in critical and severe cases (4). These indications are prominently expressed in aged persons, perhaps owing to lingering and chronic underlying diseases such as diabetes, hypertension, neurodegenerative disorders, or heart diseases (5). The spread of the virus (SARS-CoV-2) amid individuals happens when there is an infiltration of infected aerosols from cough, sneeze, or respiratory droplets into the lungs through inhalation in the nose or mouth.

Clinical case reports have documented a spectrum of neuropathological features displayed by COVID-19 patients. These neurological manifestations include anosmia, acute cerebrovascular disease, acute disseminated post-infectious encephalomyelitis, encephalitis, Guillain-Barré syndrome, acute disseminated post-infectious encephalitis, and viral meningitis (6). The presence or confirmation of SARS-CoV-2 in cerebrospinal fluid suggests that it could invade and infect the central nervous system (CNS) as a neurotropic virus inducing multiple neurological impairments (6).

This article presents the pathogenic mecha- nism of SARS-CoV-2 and neurological complications of COVID-19. Furthermore, we present the possible intervention of potential anti-COVID-19 phytochemicals in the treatment of neuropathology associated with COVID-19. The literature search for this article was done on Medline, Google Scholar, and PubMed Central using the key words: clinical features, coronavirus, SARSCOV-2, COVID-19, and complications.

\section{POSSIBLE MECHANISM BY WHICH SARS-COV-2 INDUCED NEUROLOGICAL DAMAGE}

Several mechanisms have been projected for the neuropathology linked to SARS-CoV-2 in reference to clinical manifestations displayed by COVID-19 patients. Mao et al. (7) documented hyposmia and anosmia in COVID-19 patients. This indicates that SARS-CoV-2 may be spread directly from the cribriform plate near the olfactory bulb to brain regions (8). SARS-CoV-2 can diffuse to the CNS via enteric nerve and sympathetic afferent mediated by gastrointestinal tract infection (9). Furthermore, anterograde and retrograde transmission can mediate neuro-invasion of SARS-CoV-2 through the sensory and motor nerve endings (10), coupled with involvement of motor proteins (dynein and kinesins), in particular through the vagus nerve from the lungs (11).

The brain is more vulnerable to oxidative and neuroinflammation insults due to the low level of cytoprotective endogenous enzymes. The cytokine storm syndrome (hyperinflammation) accompanying SARS-CoV-2 infections may be one of the causes of the neurological impairments observed in COVID-19 patients. Viral infections have been documented as one of the chief agents that induce secondary haemophagocytic lymphohistiocytosis (sHLH) (12). sHLH similarly referred to as macrophage activation syndrome (MAS) is a severe health disorder which includes a diverse group of hyperinflammatory conditions arising after an infringement in the interaction between genetic predisposition and initiators such as infections. One of the features of sHLH is an abrupt and severe hypercytokinaemia due to inapt persistence of histiocytes and cytotoxic T-lymphocytes, which eventually leads to multi-organ failure, haemophagocytosis, and mortality (13). Other features of sHLH include 
persistent fever, cytopenias, and hyperferritinaemia; pulmonary involvement occurs in approximately $50 \%$ of patients (14).

In the brain, the activation of glial cells cause brain damage and severe inflammation with the secretion of pro-inflammatory cytokines, including TNF-alpha, interleukin-2, and interleukin-5 (15). Neuroinvasion of SARS-CoV-2 can activate macrophage via CD4+ cells to produce interleukin-6 which is a principal constituent of cytokine storm syndrome via granulocyte-macrophage colony-stimulating factor, thus causing damage to the neuronal cells.

\section{SARS-COV-2 MECHANISM OF ACTION}

The genetic investigation on SARS-CoV-2 showed that the comprehensive genome sequence recognition rates of bat SARS coronavirus (SARSrCoV-RaTG13) and SARS-CoV were $96.2 \%$ and $79.5 \%$, respectively (16). Compared with other coronaviruses, SARS-CoV-2 proteins for viral replication, spikes formation, and nucleocapsid are initiated in specific genes in ORF1 (17). The virus (SARS-CoV-2) gain entrance into the host cell and invade it via series of cellular alterations and modifications like other types of beta-coronaviruses. Subsequently, SARS-CoV-2 binds to the angiotensin-converting enzyme 2 (ACE2) receptor in the human and/or host's alveoli of the lungs and respiratory epithelium via the RBM of the S protein $(18,19)$. A similar type of receptors has been documented in the viral genome of SARS-CoV and SARS-CoV-2, particularly, the receptor binding motif (RBM) and the receptor binding domain (RBD) (20-22). Attachment of SARS$\mathrm{CoV}$ to the receptor leads to the recruitment of cellular proteases to split the S protein into S1 and S2 domains. Transmembrane protease serine 2 (TMPRSS2), human airway trypsin-like protease (HAT) and cathepsins are the cellular proteases that cleave the spike protein and enhance additional penetration modifications $(23,24)$. The splitting of $S$ protein facilitates the activation of S2 via a conformational modification thereby allowing the insertion of the internal fusion protein (FP) into the membrane, which facilitates the entry of the virus into the host.

There is a prospect that SARS-CoV-2 utilized the mechanism similar to that of SARS-CoV as its receptor-binding domain (RBD) binding motif com- prises the nucleotides connected to ACE2. Once SARS-CoV-2 enters into its host cell, ACE2 is shed and ADAM metallopeptidase domain 17 (ADAM17) exuviate it into the extra membrane space. This resulted into high concentration of angiotensin II from the transition of angiotensin I to angiotensin II by ACE2 and concomitant respiratory distress because angiotensin II negatively regulates the renin-angiotensin pathway, and consequently damage the alveoli by increasing pulmonary vascular permeability (25). Subsequent to SARS-CoV-2 proteins translation in the host, ORF3a protein is synthesized which codes for a SARS-CoV-2 related calcium $\left(\mathrm{Ca}^{2+}\right)$ ion channel. It reacts with TNF receptor associated factor 3 (TRAF3) and initiates the transcription of nuclear factor kappa-light-chain-enhancer of activated B-cells (NF-kB) pathway, resulting in the secretion of the pro-IL-1B gene (26). ORF3a together with TRAF3 can mobilize the inflammasome complex which includes caspase 1, Nod-like receptor protein 3 (NLRP3) and apoptosis-associated specklike protein containing a CARD (ASC). Another signaling which includes caspases activation, mitochondrial damage, ROS production, and $\mathrm{Ca}^{2+}$ influx activates pro-IL-1B to interleukin 1 beta (IL-1B) which enhances cytokine production. Furthermore, ORF8b protein through NLRP3 facilitates the inflammasome pathway. ORF8b protein is longer in SARS-CoV-2 (26). Further studies are needful to ascertain the benefit or significance of the extranucleotides as contained in SARS-CoV-2. The E protein that forms an ion channel is also implicated in the cytokine's over-secretion (an occurrence referred to as cytokine storm syndromes which has been reported to be one of the major causes of respiratory distress in COVID-19) via NLRP3 inflammasome pathway (Figure 1) (27).

c-Jun N- terminal kinase (JNK) pathway is also one of the vital SARS-CoV pathogenic pathways. It is activated by ORF3a, ORF3b, and ORF7a and results in pro-inflammatory cytokines over-secretion. These over-secretions of inflammatory cytokines have deleterious effects on lung and can accelerate lungs damage (28). Secondary haemophagocytic lymphohistiocytosis (sHLH) is a cytokine profile with a hyperinflammatory syndrome described by an abrupt hypercytokinaemia with multi-organ failure, which has been reported in COVID-19 severity. This also features increased granulocyte-col- 


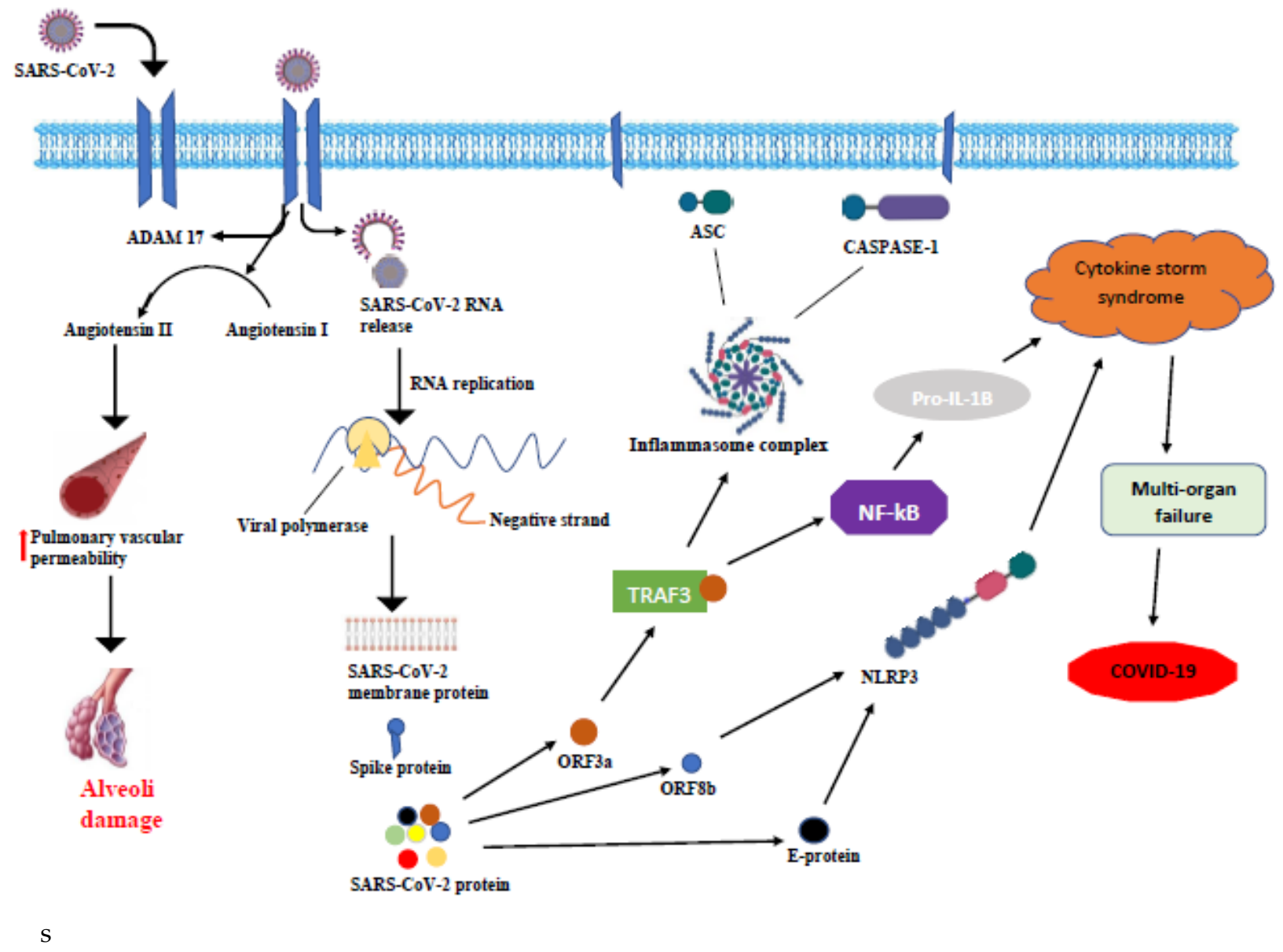

Figure 1. SARS-CoV-2 mechanism of action

ony stimulating factor, interferon- $\gamma$ inducible protein 10 , tumor necrosis factor- $\alpha$, interleukin (IL)-2, macrophage inflammatory protein $1-\alpha$, IL-7, and monocyte chemoattractant protein 1 (28).

Additionally, SARS-CoV-2 exhibited higher infectivity and transmissibility but lower mortality rate when compared with other types of respiratory syndrome coronaviruses: severe acute respiratory syndrome coronavirus (SARS-CoV) and Middle East respiratory syndrome coronavirus (MERS-CoV). The noted increase in virulence of SARS-CoV-2 may be owing to great intensity and affinity at which SARSCoV-2 attached to ACE2 and noted mutation in its genome sequence. The reported modifications on the SARS-CoV-2 gene include shorter $3 \mathrm{~b}$ segments, alteration on Nsp 2 and 3 proteins, absent $8 \mathrm{a}$, differences in orf8 and orf10 proteins, and longer $8 b(29-32)$.

\section{POLYPHENOLS WITH NEUROPROTECTIVE EFFECTS AND SARS-COV-2 INHIBITORY ACTIVITIES}

\section{Quercetin}

Quercetin, 3,3', $\quad 4^{\prime} 5,7$-pentahydroxyflavone (Figure 2) is a broadly disseminated plant polyphenol, found as conjugates with residual sugars (quercetin glycosides) in many grains, fruits, seeds, leaves, and vegetables (capers, onions, berries, and apples) (33). The highest levels of quercetin among vegetables were found in red leaf lettuce, asparagus (Asparagus officinalis L.), and onions (Allium cepa L.), while peas, green peppers, broccoli, and tomatoes contain lower levels. Quercetin arabinoside, quercetin galactoside, and quercetin glucoside are the 
<smiles>O=c1cc(-c2ccc(O)cc2)oc2cc(O)cc(O)c12</smiles>
Apigenin<smiles>O=c1c(O)c(-c2cccc(O)c2)oc2cc(O)cc(O)c12</smiles>

Quercetin

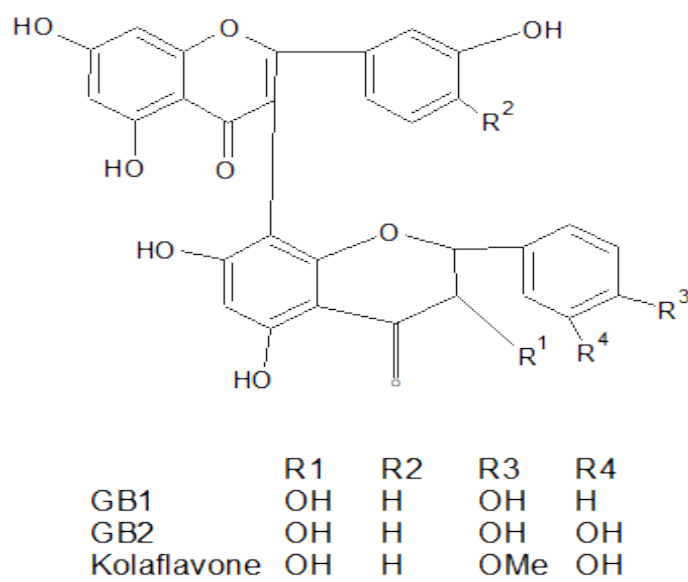

Figure 2. Basic structure of apigenin, quercetin, resveratrol and kolaviron

tables, fruits and other food items. They are first deglycosylated by gut microbiota-derived betaglucosidase or lactase phlorizin hydrolaseto quercetin aglycone before passive absorption in the small intestine (34). The quercetin aglycone produced then go through series of metabolic reactions to form methylated, sulphated, and glucuronidated metabolites, signifying participation of the phase II enzymes COMT (catechol-O-methyltransferase), SULT (sulfotransferase) and UGT (uridine 5-diphospho glucuronosyl transferase), respectively.

Studies have reported that quercetin exhibited anti-inflammatory, immunoprotective (35), antioxidant (36), and antiviral (37) effects. Its medicinal effects on cancer, nervous system disorders, gastrointestinal tract function, infections, inflammatory processes, diabetes, and cardiovascular diseases have been documented (38-40). Previous findings have documented the inhibitory activities of quer- cetin against reverse transcriptase (41), proteases (42), and polymerases (43). Also, it has been studied in models of viral infection to bind to viral capsidproteins and inhibit DNA gyrase $(44,45)$.

During viral infection, the entrance of virus into the host cell is a vital step and has been targeted as a possible point of intervention in antiviral treatments (46 - 48). Quercetin has been reported to inhibit H1N1 and H3N2 influenza infection of MDCK cells through binding to hemagglutinin proteins which is accountable for membrane fusion during virus entry and virus-mediated haemolysis (49). Furthermore, quercetin has been studied to interfere with DNA and RNA polymerases in viral infections. During adenoviruses (ADV-3,-8,-11) and herpes viruses (HSV-1, 2) infections, quercetin was reported to suppress viral DNA and RNA polymerase $(43,50,51)$ and inhibit the early stage of viral replication $(45,52)$. Li et al. (53) also reported anti- 
viral activities of quercetin against HIV via its ability to suppress protease, integrase and reverse transcriptase. Quercetin upregulated IL-13 and suppressed the levels of long terminal repeat (LTR) gene expression, TNF- $\alpha$, p24 in HIV infection (35).

Possible antiviral effect of quercetin on many types of coronaviruses has been described by $\mathrm{Yi}$ et al. (54). Quercetin metabolite have been documented to bind to SARS-CoV 3CL protease and suppressed its proteolytic activity (55). Quercetin has been studied through computational studies to interact with the S2 domain of spike protein of SARS-CoV-2, thus altering the virus entry process (56). The obstruction of virus entrance into the host cell signifies a vital approach in antiviral therapy and quercetin hinders viral membrane fusion for SARS-CoV and influenza in vitro (54).

\section{Resveratrol}

Resveratrol (3,5,4'-trihydroxystilbene) is a naturally occurring lipophilic and phenolic phytochemical found abundantly in edible plants and easily crosses the plasma membrane after oral absorption (57 - 59). It is a polyphenolic phytoalexin which comprises two aromatic rings linked by a styrene double bond which permits its trans- and cisisomers formation $(60,61)$. Resveratrol has been reported as a possible reason accountable for the French paradox $(62,63)$, a phenomenon described by an epidemiological study that the French population displayed a comparatively low rate of coronary heart disease, in spite of their high consumption of saturated fat diet $(64,65)$. A number of preclinical studies proposes that resveratrol has the capability to influence a variety of human diseases, this is due to its cardioprotective $(66,67)$, antiviral $(68,69)$, antiapoptotic $(70,71)$, anti-inflammatory $(72,73)$ antidiabetic $(74,75)$, and antioxidative $(74,76)$ properties.

Evidences from experimental studies has established the neuroprotective properties of resveratrol which may be beneficial in combating neurological disorders shown in COVID-19 patients. Resveratrol enhances enzymes that are responsible in stress response, for instance, quinone reductase 2 (QR2), a cytosolic enzyme which influences the release of destructive activated quinone and ROS, thus, exhibiting a pivotal role in the cellular response (77). Previous report has showed that QR2 is overproduced in the hippocampus of rat's brain in a model of learning deficits. Hippocampus is a brain region which is seriously affected in Alzheimer disease and it is primarily responsible for memory and learning. This indicates that the overproduction of this enzyme initiates memory impairments (78). Similarly, neuroprotective effect of resveratrol has been documented to include the inhibition of microglia-mediated neuroinflammation (79). Resveratrol has been demonstrated to inhibit the activation of NF- $\kappa \mathrm{B}$ signaling pathways and mitogen-activated protein kinases (MAPKs) in lipopolysaccharides-induced dopaminergic neuronal death (79).

Activation of microglia is the hallmark of neuroinflammation and plays a critical role in the pathogenesis of neurological diseases $(80,81)$. Microglia are the neuronal immune cells that perform a vital role in the homeostasis in the central nervous system, and act as the first line of defense during cellular assaults, oxidative damage or progression of neurological diseases in the brain (82). During microglial activation (microgliosis), different kinds of proinflammatory markers such as chemokines, prostaglandins, reactive nitrogen species, and cytokines are released. The overproduction and accumulation of these proinflammatory factors lead to the damage of the neuronal cells and ultimately cause a release of soluble factors and debris (79). Many experimental studies have demonstrated the neuroprotective ability of resveratrol to inhibit the activation of microglia (83-85). Resveratrol has been reported to suppress upsurge expression of IL-1 $\beta$, nitric oxide and TNF $\alpha$ that accompanied the activation of microglia which mediate phosphorylation of p38 and NF- $\kappa B$ signaling $(85,86)$. Resveratrol inhibited secretion of $\mathrm{TNF} \alpha$, IL- $1 \beta$ and reactive nitrogen species, and activation of microglia in the ischemic cortex (87).

Anti-covid-19 potentials of resveratrol have been reported in an in-silico study designed for drug development targeting SARS-CoV-2 Spike Protein of COVID-19 (55). The study reported that resveratrol displayed a strong binding ability with the S2 domain of SARS-CoV-2 spike protein. This spike glycoprotein, located on the surface of the virus (SARS$\mathrm{CoV}-2)$, is a class I fusion protein which enhances the initial attachment of the virus with ACE2 receptor and its consecutive fusion with the host cells (88). The ability of resveratrol to bind to this spike protein indicates that resveratrol may inhibit or alter the mechanism by which the virus gain entrance into its host. Furthermore, resveratrol has been reported to 
modulate phosphoinositide-3-kinase (PI3-k), NF-kB signaling and mitogen-activated protein kinases pathways whose end products release cytokines. These modulatory effects may provide beneficial effects in COVID-19 by inhibiting the over-secretion of inflammatory cytokines, which resulted in the occurrence of cytokine storm syndromes that accelerate lungs damage and multi-organ failure, which is related to COVID-19.

\section{Apigenin}

Apigenin (4',5,7-trihydroxyflavone) is one of the most explored phenolics and the most commonly disseminated flavonoid in many plant species. It is predominantly present in herbs (oregano, thyme, basil, chamomile), phytochemical-based beverages (tea, beer, and wine), in vegetables (parsley, celery, onions), and fruits (guava, oranges). It is also found extensively in the plant species of the genus: Matricaria, Achillea, Artemisia, and Tanacetum (89). Apigenin has been documented to have anticancer activities as well as theurapeutic effects on depression, Alzheimer's disease, amnesia, and insomnia (89). The dietary availability of apigenin could facilitate an efficacious intervention to inhibit activation of microglial and prevent the onset of Alzheimer's disease.

After absorption, apigenin can easily be transported through the circulatory system, crossing the blood-brain barrier to the brain, where it acts on the CNS and exhibits an interaction with the GABAAreceptor $(90,91)$. Sloley et al. (92) reported the inhibitory activity of apigenin on neuronal monoamine oxidases. Unregulated activities of monoamine oxidases may be one of the causes of some psychiatric cases and neurological disorders. However, monoamine oxidases inhibitors such as apigenin showed efficacy as antidepressant and anxiolytic agents.

The protective roles of apigenin in the amyloid precursor protein double transgenic Alzheimer's disease mouse has been reported by Zhao et al. (93). Apigenin is also a potent cognitionenhancing, anti-amyloidogenic, antioxidant, neuroprotective, and anti-inflammatory agent with efficacy in the prevention and/or treatment of neurodegenerative diseases (93). Nabavi et al. (94) in a review article emphasised the therapeutic potentials of apigenin in some human clinical trials and experimental animal models. Furthermore, apigenin's chemical structure, metabolism of action, and pharmacokinetics were elucidated in relation to its medicinal usefulness in depression, Parkinson's and Alzheimer's diseases (94).

Apigenin has also demonstrated strong antiinflammatory property in lipopolysaccharide-induced macrophages by reducing the level of interleukin 6 (IL-6) \{a pro-inflammatory cytokine\}. It also inhibited tumour necrosis factor (TNF- $\alpha$ ), interleukin 6, and cluster of differentiation 40 (CD40) production via suppression of interferon gammamediated STAT1 (signal transducers and activators of transcription 1) phosphorylation in microglia (95). An experimental study has established the inhibitory ability of apigenin on nuclear factor kappa-lightchain-enhancer (NF-kB), facilitated by inhibition of lipopolysaccharide-mediated phosphorylation of the p65 subunit (96). Apigenin also suppressed the activities of adhesion molecules which is very essential to mitigate oxidative stress and prevent oxidative damage (97).

Apigenin promotes the release of cytoprotective enzymes such as glutathione-s-transferase, superoxide dismutase, and catalase to inhibit and neutralize cellular oxidative. Similarly, apigenin enhances activation of Nrf-2 signaling pathway leading to increase in phase II enzymes production $(98,99)$. Anticancer property of apigenin in human cell culture models has been reported to be via suppression of angiogenesis and metastasis by interfering with the main signaling molecules in mitogenactivated protein kinase (MAPK) pathways which include c-Jun N-terminal kinases (JNK), extracellular-signal-regulated kinase (ERK), and p38 (100).

Apigenin has been documented to interact with both S1 and S2 domains of the spike protein of SARS-COV-2 with substantial binding energies thus unsettling viral attachment and internalization into the host (56). Similarly, in silico study in our laboratory revealed that apigenin displayed a significant binding affinity with the SARS-CoV-2 major protease (6LU7). The result also suggested that apigenin could be a potential inhibitor of SARS-COV-2 (101).

\section{Kolaviron}

Since time immemorial, medicinal plants have become a source of novel and affordable drug compounds as plant-derived medicines have made significant impacts to human health and well-being (102 - 107). Garcinia kola (bitter kola) is a medicinal 
plant and a member of the Guttiferae family. It is an evergreen tree largely cultivated and highly esteemed for its edible nuts in West and Central Africa. Garcinia kola is commonly used by the people due to its ability to improve mouth odour and cause nervous alertness. In African traditional medicine, bitter kola is employed in the treatment and management of laryngitis, throat infections, bronchitis, inflammatory disorders, and as an antibacterial, antiparasitic, and antipurgative. The seeds have also been used in the treatment of chronic hepatitis and cholangitis with significant improvement of liver functions. Similarly, Garcinia kola seeds are used as general tonic to boost the immune system $(108,109)$.

Many experimental findings have established the traditional medicinal uses of Garcinia kola. Kolaviron, the biflavanone of Garcinia kola, has been documented to protect against oxidative stress and hepatotoxicity induced by many xenobiotics which includes aflatoxin, 2-acetylaminofluorene, carbon tetrachloride, dimethylnitrosamine, paracetamol, phalloidin in animal studies (110-113). Furthermore, the pharmacologically activities of biflavanone of Garcinia kola have been shown with many pharmacokinetic preferences over basic monomeric flavonoids as they pull through first-pass metabolism which incapacitates most flavonoids (108).

Neuroprotective abilities of kolaviron has been reported in many neuronal cell lines. Abarikwu et al. (114) documented the protective roles of kolaviron against atrazine-induced toxic insult in human dopaminergic SH-SY5Y cells. The findings revealed that the antiapoptotic and antioxidative properties of Kolaviron make it effective to prevent against atrazine-induced toxicities. Similarly, kolaviron was reported to protect against apoptotic cell death in pheochromocytoma derived (PC12) cells exposed to Atrazine (115). Igado et al. (116) reported the biochemical and morphological examination on the potential protective effects of kolaviron in vanadium-induced neuronal damage in rats. Kolaviron has been shown to suppress neuroinflammation in BV2 microglia via the Nrf2/ARE antioxidant protective mechanism (117). Also, Olajide et al. (118) reported multidirectional suppression of cortico-hippocampal neurodegeneration by kolaviron. In another study, Omotoso et al. (119) reported that kolaviron ameliorated cuprizone-induced multiple sclerosis in the brain of experimental animals.
In a recent study, we reported the neuroprotective effects of kolaviron in striatal oxidative stress and neuroinflammation associated with rotenone model of neurodegenerative disease (120). In the study, we showed that kolaviron restored rotenone-associated exploratory deficits, motor/ neuromuscular incompetence and locomotor impairment. Also, kolaviron effectively ameliorated the neurobiochemical imbalance, striatal neurodegeneration, neuroinflammation and altered antioxidant defence system in the brain of the neurodegenerative rats. Kolaviron displayed a potential capacity to enhance efficient gait with minimal severity and improved coordination. This shows that kolaviron could be a prospective drug for the effective management and/or treatment of Parkinson's disease.

Kolaviron has been noted to be a potential anti-COVID-19 drug candidate in a computational experimental study aimed to screen phytochemicals in drug repurposing approach to combat COVID-19 (101). The study employed USCF Chimera in virtual screening and molecular docking for possible inhibitors of SARS-CoV-2. Kolaviron was observed to exhibited a higher docked score with the SARS-CoV2 major protease (6LU7) above remdesivir, a recommended drug for the treatment of COVID-19. This showed that kolaviron could offer an effective inhibitory effect on SARS-CoV-2 and be a more effective drug candidate in the treatment of COVID-19.

\section{CONCLUSION}

COVID-19 is a highly infectious and severe acute respiratory disorder induced by a morbific virus referred to as SARS-CoV-2. Many COVID-19 patients have displayed neurological symptoms and signs which include anosmia, acute cerebrovascular disease, acute disseminated post-infectious encephalomyelitis, encephalitis, etc. The underlying mechanisms of pathogenic actions of SARS-CoV-2 include those activated by ORF3a, ORF3b, and ORF7a via the JNK pathway, which induces lung damage; reduction of ACE2 to enhance pulmonary vascular permeability and damage the alveoli; immunosuppression; hyper-inflammation characterized by a fulminant and fatal hyper-cytokinaemia with multiorgan failure. Resveratrol, quercetin, kolaviron and apigenin are polyphenols from medicinal plants with proven antioxidant, anti-inflammatory, and pharmacological activities that can inhibit SARSCoV-2 and mitigate COVID-19. These polyphenols 
have been documented to suppress JNK and MAPK pathways which are essential in the pathogenesis of COVID-19. SARS-Cov-2 virus infection dysregulate and exacerbate inflammatory process in the lung leading to increased secretion of IL-6 which ultimately results to a "cytokine-storm". The polyphenols with their robust anti-inflammatory properties may suppress cytokine-induced organ impairment and enhance survival in lethal infections. Taken together, resveratrol, quercetin, kolaviron and apigenin could be potential drug candidates in the treatment/management of COVID-19 mediated neuropathology.

\section{Funding}

This research was done using the authors' personal funds without specific grant from any funding agency in the public, commercial, or not-forprofit sectors.

\section{Declaration of competing interest}

The authors declare that they have no known competing financial interests or personal relationships that could have appeared to influence the work reported in this paper.

\section{References}

1. WHO COVID-19 weekly epidemiological update24 $4^{\text {th }}$ November 2020.

https://who.int/publications/m/item/weeklyepidermiological-update---24-november-2020

2. NCDC. Coronavirus COVID-19. https://covid19.ncdc.gov.ng

3. Guan W-J, Ni Z-Y, Hu Y, et al. Clinical characteristics of 2019 novel coronavirus infection in China. N Engl J Med 2020. doi:10.1056/NEJMoa2002032. https://doi.org/10.1056/NEJMoa2002032

4. World Health Organization (WHO). Q\&A on coronaviruses (COVID-19);2020. Available from: https:/www.who.int/news-room/q-a-detail/q-acoronaviruses. Accessed March 6, 2020

5. Chen N, Zhou M, Dong X et al. Epidemiological and clinical characteristics of 99 cases of 2019 novel coronavirus pneumonia in Wuhan, China: a descriptive study. Lancet 2020; 395: 507-13. https://doi.org/10.1016/S0140-6736(20)30211-7
6. Ahmed MU, Hanif M, Ali MJ, Haider MA et al. Neurological Manifestations of COVID-19 (SARSCoV-2): A Review Front Neurol 2020; 11: 518. doi: 10.3389/fneur.2020.00518 https://doi.org/10.3389/fneur.2020.00518

7. Mao L, Jin $\mathrm{H}$, Wang $\mathrm{M}$ et al. Neurologic manifestations of hospitalized patients with coronavirus disease 2019 inWuhan, China. JAMA Neurol 2020. e201127.

doi: 10.1001/jamaneurol.2020.1127

https://doi.org/10.1001/jamaneurol.2020.1127

8. Baig AM, Khaleeq A, Ali U, Syeda H. Evidence of the COVID-19virus targeting the CNS: tissue distribution, host-virus interaction, andproposed neurotropic mechanisms. ACS Chem Neurosci 2020; 11:995-8. doi: 10.1021/acschemneuro.0c00122 https://doi.org/10.1021/acschemneuro.0c00122

9. Wong SH, Lui RN, Sung JJ. Covid-19 and the digestive system. J Gastroenterol Hepatol 2020; 35:744-8. doi: 10.1111/jgh.15047

https://doi.org/10.1111/igh.15047 
10. Swanson PA. $2^{\text {nd }}$, McGavern DB. Viral diseases of the central nervous system. Curr Opin Virol 2015; 11:44-54. doi: 10.1016/j.coviro.2014.12.009 https://doi.org/10.1016/j.coviro.2014.12.009

11. Li YC, Bai WZ, Hashikawa T. The neuroinvasive potential of SARS-CoV2 mayplay a role in the respiratory failure of COVID-19 patients. J Med Virol 2020; 92:552-5. doi: 10.1002/jmv.25728 https://doi.org/10.1002/jmv.25728

12. Ramos-Casals M, Brito-Zeron $P$, Lopez-Guillermo A et al. Adult haemophagocytic syndrome. Lancet 2014; 383: 1503-16. https://doi.org/10.1016/S0140-6736(13)61048-X

13. Henter JI, Samuelsson-Harne A, Arico $\mathrm{M}$ et al. Treatment of haemophagocytic lymphohistiocytosis with HLH-94 immunochemotherapy and bone marrow transplantation. Blood 2002; 100: 2367-73. https://doi.org/10.1182/blood-2002-01-0172

14. Seguin A, Galicier L, Boutboul D et al. Pulmonary involvement in patients with hemophagocytic lymphohistiocytosis. Chest 2016; 149: 1294-301. https://doi.org/10.1016/j.chest.2015.11.004

15. Bohmwald K, Gálvez NMS, Ríos M, Kalergis AM. Neurologic alterationsdue to respiratory virus infections. Front Cell Neurosci 2018; 12: 386. doi: 10.3389/fncel.2018.00386 https://doi.org/10.3389/fncel.2018.00386

16. Chen N, Zhou M, Dong X et al. Epidemiological and clinical characteristics of 99 cases of 2019 novel coronavirus pneumonia in Wuhan, China: a descriptive study. Lancet 2020; 395: 507-13. https://doi.org/10.1016/S0140-6736(20)30211-7

17. van Boheemen $S$, de Graaf $M$, Lauber $C$ et al. Genomic characterization of a newly discovered coronavirus associated with acute respiratory distress syndrome in humans. M Bio 2012; 3(6): e00473-e512.

https://doi.org/10.1128/mBio.00473-12

18. Phan T. Novel coronavirus: from discovery to clinical diagnostics. Infect Genet Evo 2020; 79, 104211.

https://doi.org/10.1016/j.meegid.2020.104211
19. Liu Z, Xiao $X$,Wei $X$ et al. Composition and divergence of coronavirus spike proteins and host ACE2 receptors predict potential intermediate hosts of SARS-CoV-2. J Med Virol 2020b. https://doi.org/10.1002/jmv.25726

20. Glowacka I, Bertram S, Müller MA et al. Evidence that TMPRSS2 activates the severe acute respiratory syndrome coronavirus spike protein for membrane fusion and reduces viral control by the humoral immune response. J Virol 2011; 85(9):4122-34.

https://doi.org/10.1128//VI.02232-10

21. Bertram S, Glowacka I, Müller MA et al. Cleavage and activation of the severe acute respiratory syndrome coronavirus spike protein by human airway trypsin-like protease. J Virol 2011; 85 (24):13363-72.

https://doi.org/10.1128//VI.05300-11

22. Chan JF, To KK, Tse $\mathrm{H}$ et al. Interspecies transmission and emergence of novel viruses: lessons from bats and birds. Trends Microbiol 2013; 21:544-55.

https://doi.org/10.1016/j.tim.2013.05.005

23. Siu KL, Yuen KS, Castaño-Rodriguez $C$ et al. Severe acute respiratory syndrome coronavirus ORF3a protein activates the NLRP3 inflammasome by promoting TRAF3-dependent ubiquitination of ASC. FASEB J 2019; 33: 8865-77. https://doi.org/10.1096/fj.201802418R

24. Nieto-Torres JL, Verdiá-Báguena C, JimenezGuardeño JM et al. Severe acute respiratory syndrome coronavirus $\mathrm{E}$ protein transports calcium ions and activates the NLRP3 inflammasome. Virology 2015; 485: 330-9.

https://doi.org/10.1016/j.virol.2015.08.010.

25. Huang C, Wang Y, Li X, et al. Clinical features of patients infected with 2019 novel coronavirus in Wuhan, China. Lancet 2020; 395: 497-506. https://doi.org/10.1016/S0140-6736(20)30183-5

26. Wu A, Peng Y, Huang B et al. Genome composition and divergence of the novel coronavirus (2019$\mathrm{nCoV}$ ) originating in China. Cell Host Microbe 2020a; 27: 325-8. https://doi.org/10.1016/j.chom.2020.02.001 
27. Wu C, Liu Y, Yang Y et al. Analysis of therapeutic targets for SARS-CoV-2 and discovery of potential drugs by computational methods. Acta Pharm Sin B 2020b; https://doi.org/10.1016/j.apsb.2020.02.008

28. Xu J, Zhao S, Teng $\mathrm{T}$ et al. Systematic comparison of two animal-to-human transmitted human coronaviruses: SARS-CoV-2 and SARS-CoV. Viruses 2020a; 12: 244. https://doi.org/10.3390/v12020244.

29. $\mathrm{Xu} X, \mathrm{Yu} \mathrm{C}, \mathrm{Qu} J$ et al. Imaging and clinical features of patients with 2019 novel coronavirus SARSCoV-2. Eur J Nucl Med Mol Imaging 2020b; 1-6

https://doi.org/10.1007/s00259-020-04735-9

30. Yin Y, Wunderink RG. MERS, SARS and other coronaviruses as causes of pneumonia. Respirology 2018; 23: 130-7.

https://doi.org/10.1111/resp.13196.

31. Zhao Y, Zhao Z, Wang Y et al. Single-cell RNA expressionprofilingof ACE2, the putative receptor of Wuhan 2019-nCov. BioRxiv 2020; https://doi.org/10.1101/2020.01.26.919985

32. Tai $\mathrm{W}, \mathrm{He} \mathrm{L}, \mathrm{Zhang} \mathrm{X}$ et al. Characterization of the receptor-binding domain (RBD) of 2019 novel coronavirus: implication for developmentof RBD protein as a viral attachment inhibitor and vaccine. Cell Mol Immunol 2020; 1-8 https://doi.org/10.1038/s41423-020-0400-4

33. Li Y, Yao J, Han C et al. Quercetin, inflammation and immunity. Nutrients 2016; 8: 167. https://doi.org/10.3390/nu8030167

34. Guo Y, Bruno RS. Endogenous and exogenous mediators of quercetin bioavailability. J Nutr Biochem 2015; 26: (3) 201-10.

https://doi.org/10.1016/j.jnutbio.2014.10.008

35. Nair MP, Kandaswami C, Mahajan S et al. The flavonoid, quercetin, differentially regulatesTh-1 (IFNgamma) and Th-2 (IL4) cytokine gene expression by normalperipheral blood mononuclear cells. Biochim Biophys Acta 2002; 1593: 29-36. https://doi.org/10.1016/S0167-4889(02)00328-2
36. Robaszkiewicz A, Balcerczyk A, Bartosz G. Antioxidative and prooxidativeeffects of quercetin on A549 cells. Cell Biol Int 2007 31: 1245-50. doi: 10.1016/j.cellbi.2007.04.009 https://doi.org/10.1016/j.cellbi.2007.04.009

37. Uchide N, Toyoda H. Antioxidant therapy as a potential approachto severe influenza-associated complications. Molecules 2011;16: 2032 - 52. https://doi.org/10.3390/molecules16032032

38. Kelly GS. Quercetin. Monograph, Altern Med Rev 2011; 16: (2) 172-94.

39. Russo M, Spagnuolo C, Tedesco I et al. The flavonoid quercetin in disease prevention and therapy:facts and fancies. Biochem Pharmacol 2012; 83: (1) 6-15.

https://doi.org/10.1016/j.bcp.2011.08.010

40. Boots AW, Haenen GRMM, Bast A. Health effects ofquercetin: from antioxidant to nutraceutical. Eur J Pharmacol 2008; 585: 325-37.

https://doi.org/10.1016/j.ejphar.2008.03.008

41. Spedding G, Ratty A, Middleton E Jr. Inhibition of reverse transcriptases by flavonoids. Antiviral Res 1989; 12: 99-110.

\section{https://doi.org/10.1016/0166-3542(89)90073-9}

42. Bachmetov L, Gal-Tanamy M, Shapira A et al. Suppression of hepatitis $C$ virus by the flavonoidquercetin is mediated by inhibition of NS3 protease activity. J Viral Hepat 2012; 19:e81-8. https://doi.org/10.1111/j.1365-2893.2011.01507.x

43. Shinozuka K, Kikuchi Y, Nishino C et al. Inhibitory effectof flavonoids on DNA-dependent DNA and RNA polymerases. Experientia 1988; 44: 882-5.

https://doi.org/10.1007/BF01941188

44. Cushnie TP, Lamb AJ. Antimicrobial activity of flavonoids. Int J Antimicrob Agents 2005; 26:343-56. https://doi.org/10.1016/j.ijantimicag.2005.09.002

45. Debiaggi M, Tateo F, Pagani L et al. Effects ofpropolis flavonoids on virus infectivity and replication. Microbiologica 1990; 13:207-13. 
46. Liu S, Wu S, Jiang S. HIV entry inhibitors targeting gp41: frompolypeptides to small-molecule compounds. Curr Pharm Des 2007; 13: 143-62. https://doi.org/10.2174/138161207779313722

47. Yang J, Li M, Shen X, Liu S. Influenza A virus entry inhibitors targeting the hemagglutinin. Viruses 2013; 5:352-73. https://doi.org/10.3390/v5010352

48. Xia S, Liu Q, Wang $Q$ et al. Middle East respiratory syndrome coronavirus (MERS-CoV) entry inhibitors targeting spike protein. Virus Res 2014; 194:200-10.

https://doi.org/10.1016/j.virusres.2014.10.007

49. $\mathrm{Wu} \mathrm{W}, \mathrm{Li} \mathrm{R}, \mathrm{Li} \mathrm{X}$ et al. Quercetin as anantiviral agent inhibits Influenza A Virus (IAV) entry. Viruses 2015; 8: 6.

https://doi.org/10.3390/v8010006

50. Ono K, Nakane H. Mechanisms of inhibition of various cellular DNA and RNA polymerases by several flavonoids. J Biochem 1990; 108:609-13. https://doi.org/10.1093/oxfordjournals.jbchem.a12 $\underline{3251}$

51. Ono K, Nakane H, Fukushima M et al. Differential inhibitory effects of various flavonoids on the activities of reverse transcriptase and cellular DNA and RNA polymerases. Eur J Biochem 1990; 190:469-76. https://doi.org/10.1111/j.1432-1033.1990.tb15597.x

52. Chiang LC, Chiang W, Liu MC, Lin CC. In vitro antiviral activities of Caesalpinia pulcherrima and its related flavonoids. J Antimicrob Chemother 2003; 52:194-8.

https://doi.org/10.1093/jac/dkg291

53. Li BW, Zhang FH, Serrao E et al. Design and discovery of flavonoid-based HIV-1 integrase inhibitors targeting both the active site and the interaction with LEDGF/p75. Bioorg Med Chem 2014;

https://doi.org/10.1016/j.bmc.2014.04.016

54. Yi L, Li Z, Yuan K et al. Small molecules blockingthe entry of severe acute respiratory syndrome coronavirus into host cells. J Virol 2004; 78:11334. https://doi.org/10.1128//VI.78.20.11334-11339.2004
55. Chen L, Li J, Luo $\mathrm{C}$ et al. Binding interaction of quercetin-3-beta-galactoside and its synthetic derivatives with SARS-CoV 3CL(pro): structureactivity relationship studies revealsalient pharmacophore features. Bioorg Med Chem 2006; 14:8295-306.

https://doi.org/10.1016/j.bmc.2006.09.014

56. Jitendra SR, Aroni C, Abhijeet K, Shashikant R. Targeting SARS-CoV-2 spike protein of COVID19 with naturally occurring phytochemicals: An in silico study for drug development. ChemRxiv Preprint 2020; https://doi.org/10.26434/chemrxiv.12094203.v1.

57. Jeandet P, Douillet-Breuil AC, Bessis $\mathrm{R}$ et al. Phytoalexins from the Vitaceae: Biosynthesis, phytoalexin gene expression in transgenic plants, antifungal activity, and metabolism. J Agric Food Chem 2002; 50: 2731-41. https://doi.org/10.1021/jf011429s

58. de Santi C, Pietrabissa A, Mosca F, Pacifici GM. Glucuronidation of resveratrol, a natural product present ingrape and wine, in the human liver. Xenobiotica 2000; 30: 1047-54. https://doi.org/10.1080/00498250010002487

59. De Santi C, Pietrabissa A, Spisni R et al. Sulphation of resveratrol, a natural compound present inwine, and its inhibition by natural flavonoids. Xenobiotica 2000; 30: 857-66. https://doi.org/10.1080/004982500433282

60. Ribeiro de Lima MT, Waffo-Teguo P, Teissedre PL et al. Determination of stilbenes (trans-astringin, cisand trans-piceid, andcis- and trans-resveratrol) in Portuguese wines. J Agric Food Chem 1999; 47: 2666-70.

https://doi.org/10.1021/jf9900884

61. BerzasNevado JJ, Contento Salcedo AM, CastanedaPenalvo G. Simultaneous determination of cis- and transresveratrolin wines by capillary zone electrophoresis. Analyst 1999; 124: 61-6. https://doi.org/10.1039/a807226d

62. Kopp P. Resveratrol, a phytoestrogen found in red wine. A possible explanation for the conundrum of the 'French paradox'? Eur J Endocrinol 1998; 138: 619-20. 
https://doi.org/10.1530/eje.0.1380619

63. Hengst JA, Yun JK. Sphingosine kinase: A key tosolving the 'French Paradox'? Br J Pharmacol 2012; 166: 1603-04. https://doi.org/10.1111/j.1476-5381.2012.01898.x

64. Ferrieres J. The French paradox: Lessons for othercountries. Heart 2004; 90: 107-11.

https://doi.org/10.1136/heart.90.1.107

65. Constant J. Alcohol, ischemic heart disease, and theFrench paradox. Coron Artery Dis 1997; 8: 645-9. https://doi.org/10.1097/00019501-199710000-00007

66. Wang Z, Zou J, Cao K et al. Dealcoholized red wine containing known amounts ofresveratrol suppresses atherosclerosis in hypercholesterolemic rabbits without affecting plasma lipid levels. Int J Mol Med 2005; 16: 533-40.

67. Szmitko PE, Verma S. Cardiology patient pages. Red wine and your heart. Circulation 2005; 111: e10-11. https://doi.org/10.1161/01.CIR.0000151608.29217.62

68. Berardi V, Ricci F, Castelli M et al. Resveratrol exhibits a strong cytotoxic activity in cultured cellsand has an antiviral action against polyomavirus: potential clinical use. J. Exp Clin Cancer Res 2009; $28: 96$. https://doi.org/10.1186/1756-9966-28-96

69. Clouser CL, Chauhan J, Bess MA et al. Anti-HIV-1 activity of resveratrol derivatives and synergistic inhibition of HIV-1by the combination of resveratrol and decitabine. Bioorg Med Chem Lett 2012; 22: 6642-6.

https://doi.org/10.1016/j.bmcl.2012.08.108

70. Nicolini G, Rigolio R, Miloso M et al. Anti-apoptotic effect of trans-resveratrol on paclitaxel induced apoptosis in the human neuroblastoma SH-SY5Y cell line. Neurosci Lett 2001; 302: 41-4. https://doi.org/10.1016/S0304-3940(01)01654-8

71. Baarine M, Thandapilly SJ, Louis XL et al. Proapoptotic versus anti-apoptotic properties of dietary resveratrol ontumoral and normal cardiac cells. Genes Nutr 2011; 6: 161-9.

https://doi.org/10.1007/s12263-011-0232-z
72. Udenigwe CC, Ramprasath VR, Aluko RE, Jones PJ. Potential of resveratrol in anticancer and antiinflammatorytherapy. Nutr Rev 2008; 66: 445-54. https://doi.org/10.1111/j.1753-4887.2008.00076.x

73. Chen G, Shan W, Wu Y et al. Synthesis and antiinflammatory activity of resveratrol analogs. Chem Pharm Bull 2005; 53: 1587-90.

https://doi.org/10.1248/cpb.53.1587

74. Chang CC, Chang CY, Huang JP, Hung LM. Effect of resveratrol on oxidative and inflammatory stress inliver and spleen of streptozotocin-induced type 1 diabetic rats. Chin J Physiol 2012; 55: 192-201. https://doi.org/10.4077/CJP.2012.BAA012

75. Dao TM, Waget A, Klopp P et al. Resveratrol increases glucoseinduced GLP-1 secretion in mice: A mechanism which contributes tothe glycemic control. PLoS One 2011; 6: No. e20700. https://doi.org/10.1371/journal.pone.0020700

76. Spanier G, Xu H, Xia N et al. Resveratrol reduces endothelialoxidative stress by modulating the gene expression of superoxidedismutase 1 (SOD1), glutathione peroxidase 1 (GPx1) and NADPH oxidase subunit (Nox4). J Physiol Pharmacol 2009; 60: 111-6.

77. Vella F, Ferry G, Delagrange P, Boutin JA. NRH:quinone reductase 2: an enzyme of surprises and mysteries. Biochem Pharmacol 2005; 71: 1-12. https://doi.org/10.1016/j.bcp.2005.09.019

78. Benoit CE, Bastianetto S, Brouillette J et al. Loss of quinone reductase 2 function selectively facilitates learning behaviors. J Neurosci 2010; 30: 12690-700. https://doi.org/10.1523/INEUROSCI.2808-10.2010

79. Zhang F, Liu J, Shi JS. Anti-inflammatory activities of resveratrol in the brain: role of resveratrol in microglial activation. Eur J Pharmacol 2010; 636: 1-7. https://doi.org/10.1016/j.ejphar.2010.03.043

80. Block ML, Hong JS. Chronic microglialactivation and progressive dopaminergic neurotoxicity. Biochem SocTrans 2007; 35: 1127-32. https://doi.org/10.1042/BST0351127 
81. Gao HM, Liu B, Zhang W, Hong JS. Novel antiinflammatory therapy for Parkinson's disease. Trends Pharmacol Sci 2003; 24: 395-401. https://doi.org/10.1016/S0165-6147(03)00176-7

82. Ransohoff RM, Perry VH. Microglial physiology: Unique stimuli, specialized responses. Ann Rev Immunol 2009; 27: 119-45.

https://doi.org/10.1146/annurev.immunol.021908.1 $\underline{32528}$

83. Candelario-Jalil E, de Oliveira AC, Graf $\mathrm{S}$ et al. Resveratrol potently reduces prostaglandin E2 production and free radical formation inlipopolysaccharide-activated primary rat microglia. J Neuroinflammation 2007; 4: 25. https://doi.org/10.1186/1742-2094-4-25

84. Lorenz P, Roychowdhury S, Engelmann M et al. Oxyresveratrol and resveratrol are potentantioxidants and free radical scavengers: Effect on nitrosative andoxidative stress derived from microglial cells. Nitric Oxide 2003; 9: 64-76. https://doi.org/10.1016/i.niox.2003.09.005

85. Bi XL, Yang JY, Dong YX et al. Resveratrol inhibits nitric oxide and TNF-alpha production by lipopolysaccharide-activated microglia. Int Immunopharmacol 2005; 5: 185-93. https://doi.org/10.1016/j.intimp.2004.08.008

86. Bureau G, Longpre F, Martinoli MG. Resveratrol and quercetin, two natural polyphenols, reduce apoptoticneuronal cell death induced by neuroinflammation. J Neurosci Res 2008; 86: 403-10. https://doi.org/10.1002/jnr.21503

87. Shin JA, Lee H, Lim YK et al. Therapeutic effects of resveratrol during acute periods following experimental ischemic stroke. J. Neuroimmunol 2010; 227: 93-100. https://doi.org/10.1016/i.jneuroim.2010.06.017

88. Oladele JO, Ajayi EIO, Oyeleke OM et al. Asystematic review on COVID-19 pandemic with special emphasis on Curative potentials ofmedicinal plants. Heliyon 2020; 6: 1-17.

https://doi.org/10.1016/j.heliyon.2020.e04897

89. Dewick PM, Chimica, Biosintesi e Bioattivitàdelle
Sostanze Naturali; Piccin: Roma, Italy, 2001.

90. Campbell EL, Chebib M, Johnston GAR. The dietary flavonoids apigenin and (-)epigallocatechingallate enhance the positive modulation by diazepam of the activation by GABA of recombinant GABA(A)receptors. Biochem Pharmacol 2004; 68: 1631-8.

https://doi.org/10.1016/j.bcp.2004.07.022

91. Jäger AK, Krydsfeldt $K$, Rasmussen HB. Bioassayguided isolation of apigenin with GABA benzodiazepine activity from Tanacetum parthenium. Phytother Res 2009; 23: 1642-4. https://doi.org/10.1002/ptr.2816

92. Sloley BD, Urichuk LJ, Morley P, Durkin J, Shan JJ, Pang PKT, Coutts RT. Identification of kaempferol as a monoamine oxidase inhibitor and potential neuroprotectant in extracts of Ginkgo biloba leaves. J Pharm Pharmacol 2000; 52: 451-9. https://doi.org/10.1211/0022357001774075

93. Zhao L, Wang J, Liu R et al. Neuroprotective, antiamyloidogenic and neurotrophiceffects of apigenin in an Alzheimer's disease mouse model. Molecules 2013; 18: 9949-65.

https://doi.org/10.3390/molecules18089949

94. Nabavi SF, Khan H, D'onofrio G et al. Apigenin as neuroprotective agent: Of mice and men. Pharm Res 2018; 128: 359-65.

https://doi.org/10.1016/j.phrs.2017.10.008

95. Rezai-Zadeh K, Ehrhart J, Bai Y et al. Apigenin and luteolin modulate microglial activation via inhibition of STAT1-induced CD40 expression. J Neuroinflamm 2008; 5: 41-51.

https://doi.org/10.1186/1742-2094-5-41

96. Nicholas C, Batra S, Vargo MA et al. Apigenin blocks lipopolysaccharide-induced lethality in vivo and proinflammatory cytokines expression by inactivating NF-kappa B through the suppression of p65 phosphorylation. J Immunol 2007; 179: 7121-7. https://doi.org/10.4049/jimmunol.179.10.7121

97. Myhrstad MCW, Carlsen H, Nordström O, Blomhoff R, Moskaug JØ. Flavonoids increase theintracellular glutathione level by transactivation of the -glutamylcysteine synthetase catalytical 
subunitpromoter. Free Radic Biol Med 2002; 32: 38693. https://doi.org/10.1016/S0891-5849(01)00812-7

98. Paredes-Gonzalez X, Fuentes F, Jeffery $\mathrm{S}$ et al. Induction of NRF2-mediated gene expression by dietary phytochemical flavones apigenin and luteolin. Biopharm Drug Dispos 2015; 36: 440-51. https://doi.org/10.1002/bdd.1956

99. Huang CS, Lii CK, Lin AH et al. Protection by chrysin, apigenin, and luteolin against oxidative stress is mediated by the Nrf2-dependent up-regulation of hemeoxygenase 1 and glutamate cysteine ligase in rat primary hepatocytes. Arch Toxicol 2013; 87: 167-78. https://doi.org/10.1007/s00204-012-0913-4

100. Peng Q, Deng Z, Pan H et al. Mitogen-activated protein kinase signaling pathway in oral cancer. Oncol Lett 2017; 15: 1379-88. https://doi.org/10.3892/ol.2017.7491

101. Oladele JO, Oyeleke OM, Oladele OT et al. Kolaviron (Kolaflavanone), apigenin, fisetin as potential Coronavirus inhibitors: In silico investigation. Research square (preprints) 2020; 20: 1-13.

https://doi.org/10.21203/rs.3.rs-51350/v1

102. Oladele JO, Oladele OT, Ademiluyi AO et al. Chaya (Jatropha tanjorensis) leafs protect against sodium benzoate mediated renal dysfunction and hepatic damage in rats. Clin Phytoscience 2020; 6(13): 1-8.

\section{https://doi.org/10.1186/s40816-020-00160-5}

103. Oladele JO, Oyeleke OM, Oladele OT et al. Nitrobenzene-induced hormonal disruption, alteration of steroidogenic pathway, and oxidative damage in rat: protective effects of Vernonia amygdalina. Clin Phytoscience 2020; 6: 1-13. https://doi.org/10.1186/s40816-020-00161-4

104. Oladele JO, Oyeleke OM, Awosanya OO et al. Fluted Pumpkin (Telfaira occidentalis) protects against phenyl hydrazine-induced anaemia and toxicities in rats. AdvTradit Med 2020; https://doi.org/10.1007/s13596-020-00499-7

105. Oladele JO, Oyeleke OM, Oladele OT, Olaniyan MD. Neuroprotective mechanism of Vernonia amygdalina in a rat model of neurodegenerative diseases. Toxicol Rep 2020; 7: 1223 - 32. https://doi.org/10.1016/j.toxrep.2020.09.005

106. Oladele JO, Oyewole OI, Bello OK, Oladele OT. Hepatoprotective Effect of Aqueous Extract of Telfairia occidentalis on Cadmium ChlorideInduced Oxidative Stress and Hepatotoxicity in Rats. J Drug Des Med Chem 2017; 3(3): 32-6. https://doi.org/10.11648/j.jddmc.20170303.11

107. Oyewole OI, Oladele JO, Oladele OT. Methanolic leaf extract of Ficus Exasperata Leaf attenuates Arsenate-Mediated hepatic and renal oxidative stress in rats. Res J Health Sci 2017; 5(2): 115- 23. https://doi.org/10.4314/rejhs.v5i2.7

108. Iwu MM. Antihepatotoxic constituents of Garcinia kola seeds. Experientia 1985; 41: 699-70.

https://doi.org/10.1007/BF02007729

109. Taiwo O, Xu HX, Lee SF. Antibacteria activities of extracts from Nigerian chewing sticks. Phytother Res 1999; 13: 675-9.

https://doi.org/10.1002/(SICI)10991573(199912)13:8<675::AID-PTR513>3.0.CO;2-X

110. Farombi EO, Tahnteng JG, Agboola AO, Nwankwo JO, Emerole GO. Chemoprevention of 2-acetylaminofluorene-induced hepatotoxicity and lipid peroxidation in rats by kolaviron-a Garcinia kola seed extract. Food Chem Toxicol 2000; 38: 535-41. https://doi.org/10.1016/S0278-6915(00)00039-9

111. Farombi EO, Adepoju BF, Ola-Davies OE, Emerole GO. Chemoprevention of aflatoxin B1-induced genotoxicity and hepatic oxidative damage in rats by kolaviron, a natural biflavonoid of Garcinia kola seeds. Eur J Cancer Prev 2005; 14: 207-14.

https://doi.org/10.1097/00008469-200506000-00003

112. Farombi EO. Mechanisms for the hepatoprotective action of kolaviron: studies on hepatic enzymes, microsomal lipids and lipid peroxidation in carbontetrachloride-treated rats Pharmacol Res 2000; 42: 1, 2000. https://doi.org/10.1006/phrs.1999.0648

113. Farombi EO, Shrotriya S, Surh YJ. Kolaviron inhibits dimethyl nitrosamine-induced liver injury 
by suppressing COX-2 and iNOS expression via NF-кB and AP-1. Life Sci 2009; 84: 149-55. https://doi.org/10.1016/j.lfs.2008.11.012

114. Abarikwu SO, Farombi EO, Kashyap MP, Pant $\mathrm{AB}$. Kolaviron protects apoptotic cell death in PC12 cells exposed to Atrazine. Free Rad Res 2011; 45(9): 1061-73 https://doi.org/10.3109/10715762.2011.593177

115. Abarikwu SO, Farombi EO, Pant AB. Biflavanonekolaviron protects human dopaminergic $\mathrm{SH}-\mathrm{SY} 5 \mathrm{Y}$ cells against atrazine induced toxic insult. Toxicol in Vitro 2011; 25: 848-58.

https://doi.org/10.1016/j.tiv.2011.02.005

116. Igado OO, Olopade JO, Adesida A et al. Morphological and biochemical investigation into the possible neuroprotective effects of kolaviron (Garcinia kola bioflavonoid) on the brains of rats exposed to vanadium. Drug Chem Toxicol 2012; 35(4): 371-80.

https://doi.org/10.3109/01480545.2011.630005

117. Onasanwo SA, Velagapudi R, El-Bakoush A, Olajide OA. Inhibition of neuroinflammation in BV2 microglia by the biflavonoid kolaviron is dependent on the Nrf2/ARE antioxidant protective mechanism. Mol Cell Biochem 2016; 414: 23-6.

https://doi.org/10.1007/s11010-016-2655-8

118. Olajide OJ, Asogwa NT, Moses BO, Oyegbola CB. Multidirectional inhibition of corticohippocampal neurodegeneration by kolaviron treatment in rats. Metab Brain Dis 2017; https://doi.org/10.1007/s11011-017-0012-6

119. Omotoso GO, Ukwubile II, Arietarhire L et al. Kolaviron Protects the brain in Cuprizone-induced Model of Experimental Multiple Sclerosis via enhancement of intrinsic antioxidant mechanisms: Possible Therapeutic Applications? Pathophysiol 2018; 25: 299-306.

https://doi.org/10.1016/j.pathophys.2018.04.004

120. Farombi EO, Awogbindin IO, Farombi TH et al. Neuroprotective role of kolaviron in striatal redoinflammation associated with rotenone model of Parkinson's disease. Neurotoxicol 2019; 73:132-41. https://doi.org/10.1016/j.neuro.2019.03.005 


\title{
Mogući zdravstveni benefiti polifenola kod neuroloških poremećaja udruženih sa kovidom-19
}

\author{
Johnson Olaleye Oladele ${ }^{1}$, Oluwaseun Titilope Oladele², Oyedotun Moses Oyeleke \\ ${ }^{1}$ Univerzitet Kings, Departman za hemijske nauke, Odsek za biohemiju, Ode-Omu, Država Osun, Nigerija \\ ${ }^{2}$ Državni univerzitet Osun, Departman za biohemiju, Istraživačke laboratorije za fitomedicinu i molekularnu \\ toksikologiju, Osogbo, Nigerija
}

\section{S A ŽETAK}

Pojava nove bolesti izazvane korona virusom (COVID-19) predstavlja opterećenje i izazov za globalni zdravstveni sistem. Od iznenadne i nagle pojave ovog virusa 2019. godine, kod mnogih kovid-19 bolesnika javili su se neurološki simptomi i komplikacije. Do sada nije pronađen efikasan lek protiv ove visokozarazne infekcije uprkos zastrašujućoj stopi smrtnosti. Cilj ovog rada je predstavljanje mehanizma delovanja korona virusa 2 (COVID-19), kliničkih neuroloških manifestacija zabeleženih kod kovid-19 bolesnika, kao i polifenola sa neuroprotektivnim karakteristikama, koji imaju blagotvorne efekte kod neuropatologije izazvane kovidom-19. Izveštaji kliničkih studija o kovidu-19, prikazi slučajeva i slični izvori u literaturi pregledani su zbog potreba ovog rada. Neurološke komplikacije kovida-19 uključuju anosmiju, akutnu cerebrovaskularnu bolest, akutni diseminovani postinfektivni encefalomijelitis, encefalitis itd. Takođe, COVID-19 može biti i neurotropni virus zbog izolacije iz cerebrospinalne tečnosti. Mnogobrojna neurološka oštećenja mogu se javiti kod kovid-19 bolesnika zbog hiperinflamacije udružene sa SARS-CoV-2 infekcijama. Rasveratrol, kolaviron, kvercetin $i$ apigerin su polifenoli sa dokazanim antiinflamatornim $i$ terapeutskim svojstvima, koja mogu da ublaže neželjene efekte kovida-19. Potvrđeno je da ovi polifenoli suprimiraju c-Jun N-termalnu kinazu (JNK), fosfatidilinozitol 3-kinazu (PI3-K), ekstracelularnim signalom regulisanu kinazu (ERK), nuklearni faktor kapa B ćelija (NF-kB) i mitogenom aktiviranu protein kinazu (MAPK), što je esencijalno u patogenezi kovida-19. Takođe pokazali su značajnu inhibitornu aktivnost usmerenu ka SARS-CoV-2 proteinima. U celini, ovi polifenoli mogu da ispolje neuroprotektivne efekte $u$ slučaju neuropatologije izazve kovidom-19, preko modulacije puteva patogeneze.

Ključne reči: neuropatologija, polifenoli, COVID-19, SARS-CoV-2, kolaviron, apigenin, kvercetin 